\title{
$6 x^{2}-1$
}

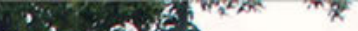

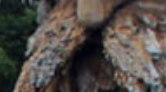
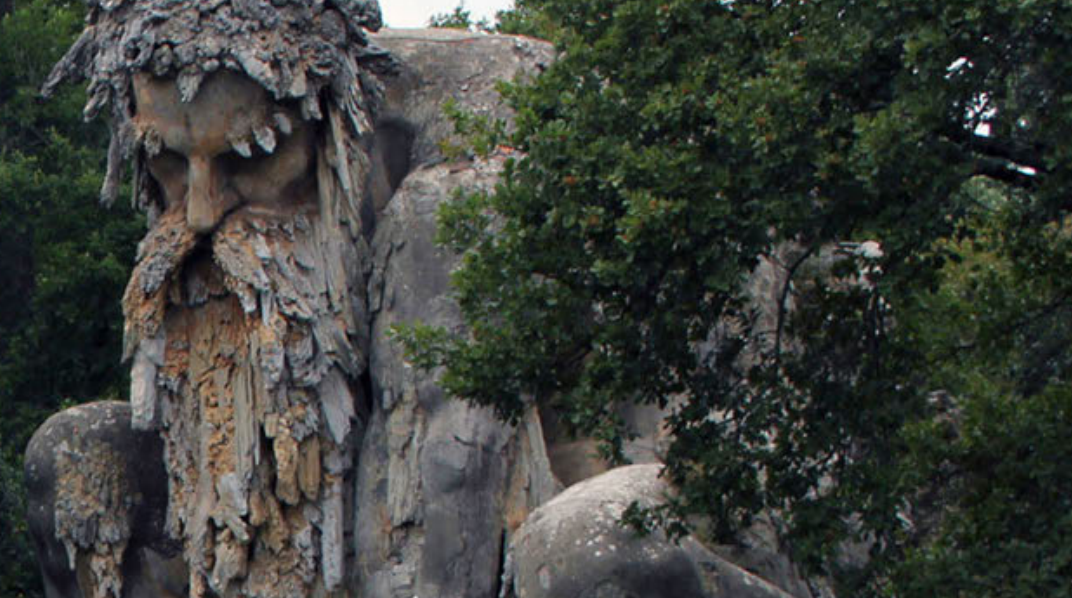

1

The

Monster

in the

Garden

3x
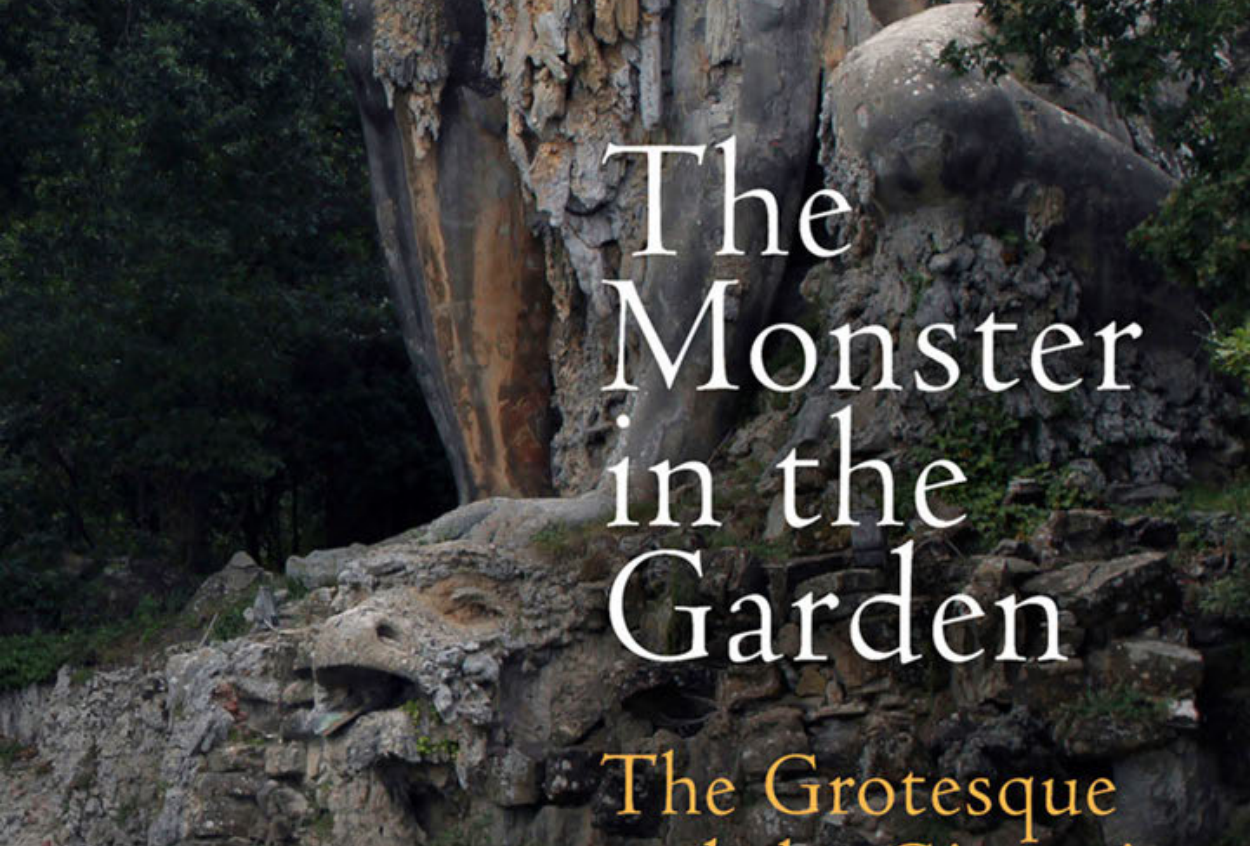

interesto

The Grotesque and the Gigantic in Renaissance Landscape-Design

Luke Morgan 


\section{The Monster in the Garden}




\title{
PENN STUDIES IN LANDSCAPE ARCHITECTURE
}

\author{
John Dixon Hunt, Series Editor
}

This series is dedicated to the study and promotion of a wide variety of approaches to landscape architecture, with special emphasis on connections between theory and practice. It includes monographs on key topics in history and theory, descriptions of projects by both established and rising designers, translations of major foreign-language texts, anthologies of theoretical and historical writings on classic issues, and critical writing by members of the profession of landscape architecture. The series was the recipient of the Award of Honor in Communications from the American Society of Landscape Architects, 2006. 


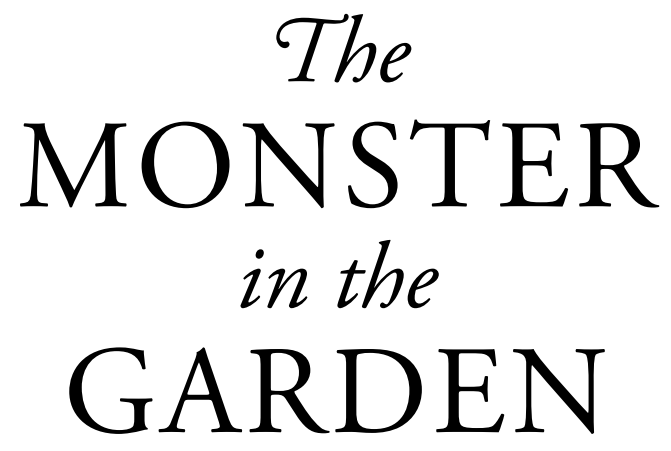

The Grotesque and the Gigantic in Renaissance Landscape Design

\title{
Luke Morgan
}

\author{
PENN \\ UNIVERSITY OF PENNSYLVANIA PRESS
}

P H I L A DE L P H I A 
Copyright (C) 2016 University of Pennsylvania Press

All rights reserved. Except for brief quotations used for purposes of review or scholarly citation, none of this book may be reproduced in any form by any means without written permission from the publisher.

Published by

University of Pennsylvania Press

Philadelphia, Pennsylvania 19104-4112

www.upenn.edu/pennpress

Printed in the United States of America on acid-free paper

$$
\begin{array}{llllllllll}
1 & 3 & 5 & 7 & 9 & 10 & 8 & 6 & 4 & 2
\end{array}
$$

A catalogue record for this book is available from the

Library of Congress.

ISBN 978-0-8122-4755-8 
For Hannah 
This page intentionally left blank 